\title{
UTERINE BLOOD FLOW IN THE PREGNANT RABBIT
}

\author{
F. M. SULLIVAN AND J. F. TUGKER* \\ Department of Pharmacology, Guys Hospital Medical School, London, S.E.1
}

(Received 7th Fune 1974)

\begin{abstract}
Summary. Two methods are described for the measurement of uterine blood flow in the pregnant rabbit. The first involves the use of a Parks ultrasonic Doppler probe placed over the exposed uterine artery. The second method uses a drop counter system connected between the uterine and jugular veins. The Doppler flowmeter was used to measure uterine arterial blood flow in twenty rabbits on Day 28 or 29 of pregnancy. No significant difference was observed between blood flow on these 2 days and the absolute blood flow to one horn ( \pm S.E.) was found to be $16 \cdot 8 \pm 1.4 \mathrm{ml} / \mathrm{min}$, equivalent to $27 \cdot 1 \pm 1.8 \mathrm{ml} / 100 \mathrm{~g}$ tissue $/ \mathrm{min}$. Using the drop recorder technique, the flow to one uterine horn in eleven rabbits on Day 27 or 28 of pregnancy was $12.5 \pm 1.9 \mathrm{ml} / \mathrm{min}$, equivalent to $23 \cdot 6 \pm 3 \cdot 2 \mathrm{ml} / 100 \mathrm{~g}$ tissue/min. The pressure-flow relationship in the uterine vascular bed was studied using the Doppler flowmeter and graded mechanical occlusion of the arterial supply. Within the range of pressures studied, the flow was found to be linearly related to the arterio-venous pressure difference. This suggests that the uterine vascular bed was fully dilated under the conditions of study.
\end{abstract}

\section{INTRODUCTION}

Studies on the pressure-flow relationships in the pregnant uterus in order to give an insight into its functional haemodynamics have so far only been reported in the sheep (Greiss, 1966a; Ladner, Brinkman, Weston \& Assali, 1970). Studies in smaller species such as the rabbit have been limited by the difficulties in determining uterine blood flow. The techniques usually employed have either involved extensive surgical procedures (Barcroft, Herkel \& Hill, 1933; Robson \& Schild, 1938; Reynolds, 1947; Ahlquist \& Woodbury, 1947; Carter, Lewis \& Bengtsson, 1966) or have yielded only single spot determinations (Assali, Douglass, Baird, Nicholson \& Suyemoto, 1953; Huckabee, 1962; Assali \& Morris, 1964; Meschia, Cotter, Makowski \& Barron, 1966; McLaurin \& Cotter, 1967; Duncan \& Lewis, 1969; Bruce \& Abdul-Karim, 1973).

In the present experiments, a Doppler ultrasonic flowmeter was used to measure uterine blood flow in the rabbit without excessive surgical preparation. The use of the Doppler ultrasonic flowmeter technique has previously been limited to qualitative analysis of blood velocity waveforms. This is the first description of its use for the quantitative determination of blood flow and full details of the methods are given. Uterine blood flow was also determined

* Present address: Department of Pharmacology, Chelsea College, London, S.W.3. 
directly with a drop recorder. This technique, although technically difficult and unsatisfactory in a number of ways, was employed in order to validate the Doppler flowmeter recordings.

\section{MATERIALS AND METHODS}

New Zealand white rabbits ( 3 to $5 \mathrm{~kg}$ ), obtained from a commercial breeder, were used throughout. The animals were mated under direct observation and the following day was designated Day 1 of pregnancy. On the 28th to 30th day of gestation, the animals were anaesthetized with sodium pentobarbitone and the trachea was cannulated. Maintenance doses of pentobarbitone were given through a cannula inserted into the left femoral vein. Maternal blood pressure was monitored from a cannula in the left femoral artery using a Devices strain gauge pressure transducer. The abdomen was opened with a mid-line suprapubic incision so that the middle third of the vagina could be seen. The right or left uterine vein and artery which run alongside the vagina were located and carefully cleared of overlying adipose tissue. Blood flow to the uterus was then measured using one of the methods described below.

\section{Blood flow measurement}

Doppler flowmeter technique. The principle of the flowmeter has been described in detail by Gosling, King, Newman \& Woodcock (1969). Briefly, the sound directed at a blood vessel is scattered by particles within the blood, mainly erythrocytes, and is altered in frequency. This shift in frequency, the Doppler shift, is proportional to the velocity of the scattering particles and, thus, with a knowledge of the cross-sectional area of a blood vessel, the flow in $\mathrm{ml} / \mathrm{min}$ can be determined. The instrument used was a Parks Model 802 Doppler flowmeter (Parks Electronics Laboratory, Beaverton, Oregon, U.S.A.), and ultrasound was transmitted at a frequency of $10 \mathrm{MHz}$ and received by two piezoelectric crystals embedded in the end of a pencil-shaped probe. Acoustic coupling of the crystals to the blood vessel was made with a special gel (Aquasonic 100: Parker Laboratories, Inc.).

The optimum angle between the acoustical axis of the crystals and the direction of blood flow is $55^{\circ}$ and this angle was maintained with the aid of a perspex holder, specially grooved to hold the blood vessel, to which the Doppler probe was attached.

The output of the flowmeter was fed into a DC 2, sub-unit $2 \mathrm{C}$ module of a Devices pen recorder, matching the impedences of the pen recorder and the flowmeter with a $110 \mathrm{k} \Omega$ series resistor. This resistor was incorporated into a low-pass filter, used as a time-constant integrator, with a choice of time constants of $0.55,1.1$ and $3.3 \mathrm{sec}$. Alternatively, the output of the flowmeter was connected directly into a Devices amplifier with sub-unit $1 \mathrm{C}$ which incorporates damping facilities. Either system allowed various degrees of smoothing to be applied to the output signal so that either the fully pulsatile output or a smoothed signal giving the mean flow could be recorded. The system was calibrated by feeding a $1-\mathrm{kHz}$ signal into the flowmeter and noting the deflection of the chart pen. 
The relationship between Doppler shift frequency and blood velocity is not wholly linear; at high blood velocities, the frequency response falls. A calibration curve was therefore constructed relating Doppler shift to mean blood velocity. The circuit used in the preparation of the calibration curve was composed of flexible silicone rubber tubing and a $30-\mathrm{mm}$ length of polythene tubing (i.d. $0.9 \mathrm{~mm}$ ) over which the Doppler probe was positioned. Whole human blood was pumped from a reservoir through the circuit with a flow inducer (model MHRE 72, Watson-Marlow Ltd, Marlow, Bucks., England). This pump has an occlusive roller type action and delivers a pulsatile flow. The outflow from the circuit was directed into a measuring cylinder to determine blood flow directly. Determinations were made at various flow rates for periods of 1 to 2 min whilst determining blood flow directly. Knowing the internal diameter of the polythene tubing, the blood flow values were converted to blood velocities and a graph of Doppler shift frequency against blood velocity was constructed.

Doppler flow measurements were made on the rabbit uterine artery between its origin and the site at which it first branches. In order to position the Doppler flow probe, the uterine vein and artery had to be separated by careful teasing. As the uterine vein is very fragile and bound very closely to the uterine artery, the separation of the two vessels is very difficult: with care it was possible to separate from the vein a length of artery 4 to $8 \mathrm{~mm}$ long. This length of artery was fixed with a few drops of formol saline so that its diameter remained constant under the probe throughout the experiment.

Anastomotic connections between the vascular beds of the left and right uterine horns of the pregnant rabbit have been demonstrated by angiography (Gothlin \& Carter, 1969). In the present experiments, these connections were occluded in the following manner. The anastomotic connection of the metered uterine vascular bed with the ovarian artery was occluded by placing a ligature around the uterotubal junction. The anastomosis between the two superior vaginal arteries was occluded by ligating the superior vaginal artery close to its origin and by tying a heavy gauge suture around the body of the uterus close to the cervix.

To convert blood velocity measurements to blood flow in $\mathrm{ml} / \mathrm{min}$, the internal diameter of the uterine artery was determined. At the end of an experiment, the external diameter of the artery was measured with a binocular microscope equipped with a micrometer eyepiece. A length of artery approximately $4 \mathrm{~mm}$ long was then excised from the area over which the Doppler probe had been positioned. A piece of tapered polythene tubing was then pushed into the lumen of the short length of vessel until the vessel's external diameter was the same as it had been in vivo. The length of the section of vessel during the determination was maintained as closely as possible to its original length. At the point at which the above criteria were satisfied, the vessel and polythene tube were severed with a sharp blade. The external diameter of the tube, and hence the internal diameter of the vessel, at the point of severance was then determined microscopically to the nearest $0.1 \mathrm{~mm}$.

Drop recorder technique. The drop recorder circuit consisted basically of a photoelectric cell drop-counting chamber connected in series with an extracorporeal loop between the uterine vein and the jugular vein. Thus, blood 
leaving one uterine horn passed through the drop counter and finally back into the body by way of the jugular vein. Initially small bore tubing (i.d. $1.5 \mathrm{~mm}$ ) was used throughout the circuit, but the pressure drop across the system was such that only very slow flow rates were recorded. When large bore silicone rubber tubing (i.d. $4.5 \mathrm{~mm}$ ) was used, satisfactory results were obtained. The cannulae necessary to connect the circuit to the uterine vein and jugular vein were made of short lengths of tapered polythene tubing. This streamlining procedure was also adopted at the inlet and outlet of the drop-counting chamber. The volume of the circuit was $14 \mathrm{ml}$. Drops were counted with a Devices drop-counting head connected through a tachograph to a Devices pen recorder.

The uterus of the anaesthetized rabbits was withdrawn from the abdomen and accommodated in a ' $U$ '-shaped Perspex dish placed over the abdomen. The connections between the metered vascular bed and collateral vascular beds were then ligated and the uterine vein and artery separated as described previously. To prevent clotting of the blood in the drop counting circuit, the animal was given $1000 \mathrm{U}$ heparin $/ \mathrm{kg}$ intravenously. The system was primed with heparinized saline and the right internal jugular vein was cannulated with the largest tapered cannula possible (usually about $4 \mathrm{~mm}$ i.d. at the small end) and connected to the outflow side of the extra-corporeal loop. A cannula of the largest possible size was tied into the uterine vein and attached to the dropcounting circuit. The time during which the blood flow to and from the uterus was arrested was kept to a minimum (usually less than $1 \mathrm{~min}$ ) to prevent damage to the fetus. The drop counter and associated tubes were lagged to prevent cooling of the blood in the extra-corporeal loop.

\section{Occlusion of the abdominal aorta}

Graded reduction of uterine arterial blood flow in the rabbit was achieved by the application of a small water-filled cuff to the abdominal aorta proximal to its division into the common iliac arteries. A catheter connecting the cuff to a syringe was led to the exterior so that graded occlusion could be achieved by varying the amount of pressure applied to the syringe.

\section{Uterine arterio-venous pressure difference measurement}

The pressure recorded from the femoral artery was considered to be representative of the pressure in the uterine artery. The mean pressure was taken as the arithmetic mean of the systolic plus diastolic pressure. A small cannula (o.d. $1.3 \mathrm{~mm}$ ) with a sharpened tip was pushed obliquely through the wall of the uterine vein and into the lumen for a distance of about $3 \mathrm{~cm}$. No leakage of blood occurred at the point of entry of the cannula into the vein. The insertion of the $1 \cdot 3-\mathrm{mm}$ diameter cannula into the uterine vein was considered to be unlikely to have any effect on blood flow in this vessel, since the approximate diameter of the vein during pregnancy is $4 \mathrm{~mm}$. Uterine venous pressure was recorded from this cannula using a Devices pressure transducer.

\section{RESULTS}

\section{Calibration of the Doppler probe}

The Doppler probe was calibrated using flow rates of 0 to $20 \mathrm{ml} / \mathrm{min}(0$ to 50 
$\mathrm{cm} / \mathrm{sec}$ ). The calibration curve obtained is shown in Text-fig. 1. The relationship was reasonably linear up to about $30 \mathrm{~cm} / \mathrm{sec}$ and agreed well with the theoretical relationship between the two parameters.

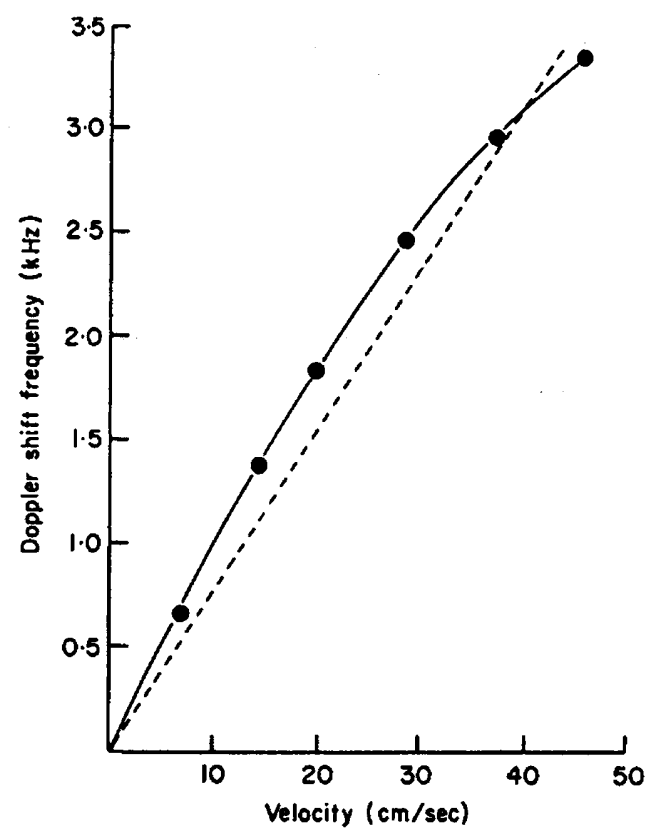

Text-pic. 1. Galibration curve for the determination of rabbit blood velocity from Doppler shift frequency readings. The dotted line shows the theoretical relationship between blood velocity and Doppler shift frequency.

\section{Uterine blood flow}

Table 1 shows the results of determinations using the Doppler flowmeter of arterial blood flow to one uterine horn in twenty rabbits on Day 28 or 29 of pregnancy. No significant difference could be shown between blood flow on the 28th and 29th day $(t=0.59, P>0 \cdot 1)$ and the results have therefore been pooled to show the overall mean values. Flow was expressed in two ways; as total uterine blood flow and as flow $/ 100 \mathrm{~g}$ perfused tissue, i.e. placentae and uterus but excluding the fetuses and amniotic fluid. There was a considerable variation in total uterine blood flow from animal to animal, the overall mean and standard error being 16.8 $\pm 1.4 \mathrm{ml} / \mathrm{min}$. When expressed in terms of $\mathrm{ml} \mathrm{blood} /$ $100 \mathrm{~g}$ of tissue perfused, however, the variation was less, being $27 \cdot 1 \pm 1 \cdot 8 \mathrm{ml} /$ $100 \mathrm{~g}$ tissue/min.

Table 2 shows the results of determinations of uterine venous blood flow on Day 27 or 28 of pregnancy in eleven rabbits using the drop recorder technique. No significant differences were found $(t=1.2, P>0.1)$, the mean $( \pm$ S.E.) uterine blood flow being $23 \cdot 6 \pm 3 \cdot 2 \mathrm{ml} / 100 \mathrm{~g}$ tissue/min.

Pressure-flow relationships in the uterine vascular bed

Four rabbits on the 28th or 29th day of gestation were prepared for the 
Table 1. Uterine arterial blood flow in twenty rabbits on the 28th or 29th day of gestation

\begin{tabular}{|c|c|c|c|c|}
\hline Day of pregnancy & $\begin{array}{l}\text { Uterine blood flow } \\
\qquad(\mathrm{ml} / \mathrm{min})\end{array}$ & $\begin{array}{l}\text { No. of fetuses } \\
\text { in horn }\end{array}$ & $\begin{array}{l}\text { Wt of uterus plus } \\
\text { placentae }(g)\end{array}$ & $\begin{array}{c}\text { Uterine blood flow } \\
(\mathrm{ml} / 100 \mathrm{~g} \text { tissue } / \mathrm{min})\end{array}$ \\
\hline $\begin{array}{l}28 \\
28 \\
28 \\
28 \\
28 \\
28 \\
28 \\
28 \\
28 \\
28 \\
28 \\
28\end{array}$ & $\begin{array}{r}24.8 \\
24.4 \\
20.0 \\
18.5 \\
17.6 \\
16.6 \\
14.2 \\
14.1 \\
12.8 \\
9.2 \\
8.0 \\
7.4\end{array}$ & $\begin{array}{l}6 \\
6 \\
5 \\
4 \\
4 \\
5 \\
6 \\
7 \\
2 \\
5 \\
4 \\
2\end{array}$ & $\begin{array}{l}79 \\
87 \\
71 \\
68 \\
56 \\
74 \\
71 \\
56 \\
30 \\
57 \\
45 \\
38\end{array}$ & $\begin{array}{l}31 \\
28 \\
30 \\
27 \\
32 \\
23 \\
20 \\
25 \\
45 \\
16 \\
18 \\
20\end{array}$ \\
\hline Mean \pm S.E. & $15 \cdot 6 \pm 1 \cdot 7$ & $4 \cdot 7$ & $61 \cdot 0$ & $26 \cdot 3 \pm 2 \cdot 3$ \\
\hline $\begin{array}{l}29 \\
29 \\
29 \\
29 \\
29 \\
29 \\
29 \\
29\end{array}$ & $\begin{array}{r}28.9 \\
25.4 \\
22.0 \\
21.4 \\
17.3 \\
14.4 \\
9.4 \\
9.3\end{array}$ & $\begin{array}{l}7 \\
7 \\
6 \\
4 \\
3 \\
3 \\
3 \\
3\end{array}$ & $\begin{array}{l}79 \\
65 \\
62 \\
77 \\
63 \\
52 \\
44 \\
68\end{array}$ & $\begin{array}{l}37 \\
37 \\
35 \\
28 \\
27 \\
28 \\
21 \\
14\end{array}$ \\
\hline Mean \pm S.E. & $18 \cdot 5 \pm 2 \cdot 5$ & $4 \cdot 5$ & $63 \cdot 8$ & $28 \cdot 4 \pm 2 \cdot 9$ \\
\hline $\begin{array}{l}\text { Overall mean } \\
\pm \text { S.E. }\end{array}$ & $16 \cdot 8 \pm 1 \cdot 4$ & $4 \cdot 6$ & $62 \cdot 1$ & $27 \cdot 1 \pm 1 \cdot 8$ \\
\hline
\end{tabular}

Table 2. Uterine venous blood flow in eleven rabbits on the 27 th or 28 th day of gestation

\begin{tabular}{|c|c|c|c|c|}
\hline Day of pregnancy & $\begin{array}{l}\text { Uterine blood flow } \\
(\mathrm{ml} / \mathrm{min})\end{array}$ & $\begin{array}{l}\text { No. of fetuses } \\
\text { in hom }\end{array}$ & $\begin{array}{l}\text { Wt of uterus plus } \\
\text { placentae }(\mathrm{g})\end{array}$ & $\begin{array}{c}\text { Uterine blood flow } \\
(\mathrm{ml} / 100 \mathrm{~g} \text { tissue } / \mathrm{min})\end{array}$ \\
\hline $\begin{array}{l}27 \\
27 \\
27 \\
27 \\
27\end{array}$ & $\begin{array}{r}18.0 \\
17.0 \\
7.0 \\
6.5 \\
6.0\end{array}$ & $\begin{array}{l}5 \\
4 \\
5 \\
4 \\
3\end{array}$ & $\begin{array}{l}62.0 \\
61 \cdot 0 \\
60.0 \\
41.0 \\
45.0\end{array}$ & $\begin{array}{l}29 \\
28 \\
12 \\
16 \\
13\end{array}$ \\
\hline Mean \pm S.E. & $10 \cdot 9 \pm 2 \cdot 7$ & $4 \cdot 2$ & $53 \cdot 8$ & $19 \cdot 6 \pm 3 \cdot 7$ \\
\hline $\begin{array}{l}28 \\
28 \\
28 \\
28 \\
28 \\
28\end{array}$ & $\begin{array}{r}26.0 \\
16.5 \\
11.0 \\
11.0 \\
9.0 \\
9.0\end{array}$ & $\begin{array}{l}5 \\
4 \\
5 \\
6 \\
2 \\
3\end{array}$ & $\begin{array}{l}61 \cdot 0 \\
43.5 \\
62.5 \\
81 \cdot 0 \\
31 \cdot 0 \\
44.0\end{array}$ & $\begin{array}{l}43 \\
38 \\
18 \\
14 \\
29 \\
20\end{array}$ \\
\hline Mean \pm S.E. & $13 \cdot 8 \pm 2 \cdot 7$ & $4 \cdot 2$ & $53 \cdot 8$ & $27 \cdot 0 \pm 4 \cdot 8$ \\
\hline $\begin{array}{l}\text { Overall mean } \\
\quad \pm \text { S.E. }\end{array}$ & $12 \cdot 5 \pm 1 \cdot 9$ & $4 \cdot 2$ & $53 \cdot 8$ & $23 \cdot 6 \pm 3 \cdot 2$ \\
\hline
\end{tabular}


measurement of uterine arterial and venous pressure and arterial flow using the Doppler flowmeter. Special care was taken to occlude the anastomotic connections of the metered bed with collateral vascular beds. In the first series of experiments, various degrees of aortic occlusion of 1 to 1.5 min duration were employed. A series of pressure-flow values were obtained by reducing the arterial pressure by aortic occlusion and observing the change in uterine blood flow. After each determination, the clamp was released and the pressure allowed to return to normal before making another determination.

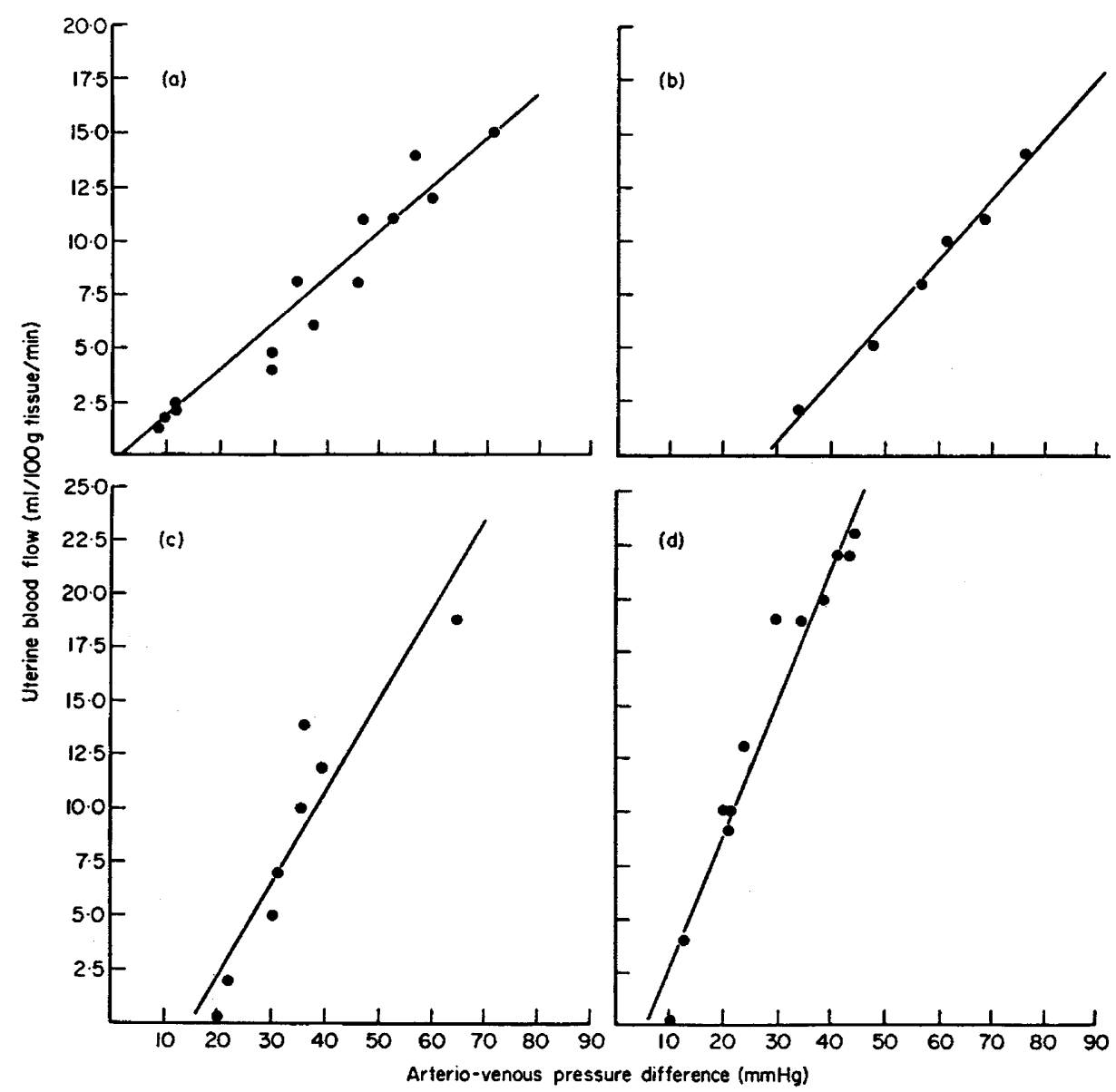

TEXT-FIG. 2. The relationship between uterine arterio-venous pressure difference and uterine arterial blood flow in four rabbits. a,b, Day 28 of pregnancy; c,d, Day 29 of pregnancy.

The results of the studies in the four rabbits are shown in Text-fig. 2. Although there was no objective statistical test for non-linearity in these circumstances, visual inspection of the results failed to reveal any systematic curvilinearity, showing that, within the range of pressures studied, the uterine blood flow was linearly related to the uterine arterio-venous pressure difference. 
In each rabbit, reduction of perfusion pressure resulted in an immediate fall in blood flow which showed no tendency to increase towards the previous value but remained constant until the perfusion pressure was again altered. The possibility that flow might show signs of a return to normal if perfusion pressure was reduced for periods of time greater than 1 to 1.5 min was investigated. Perfusion pressure was reduced for $4 \mathrm{~min}$ in one rabbit and flow was observed during this period (Text-fig. 3). The flow showed no tendency to return to its previous value after the initial fall.
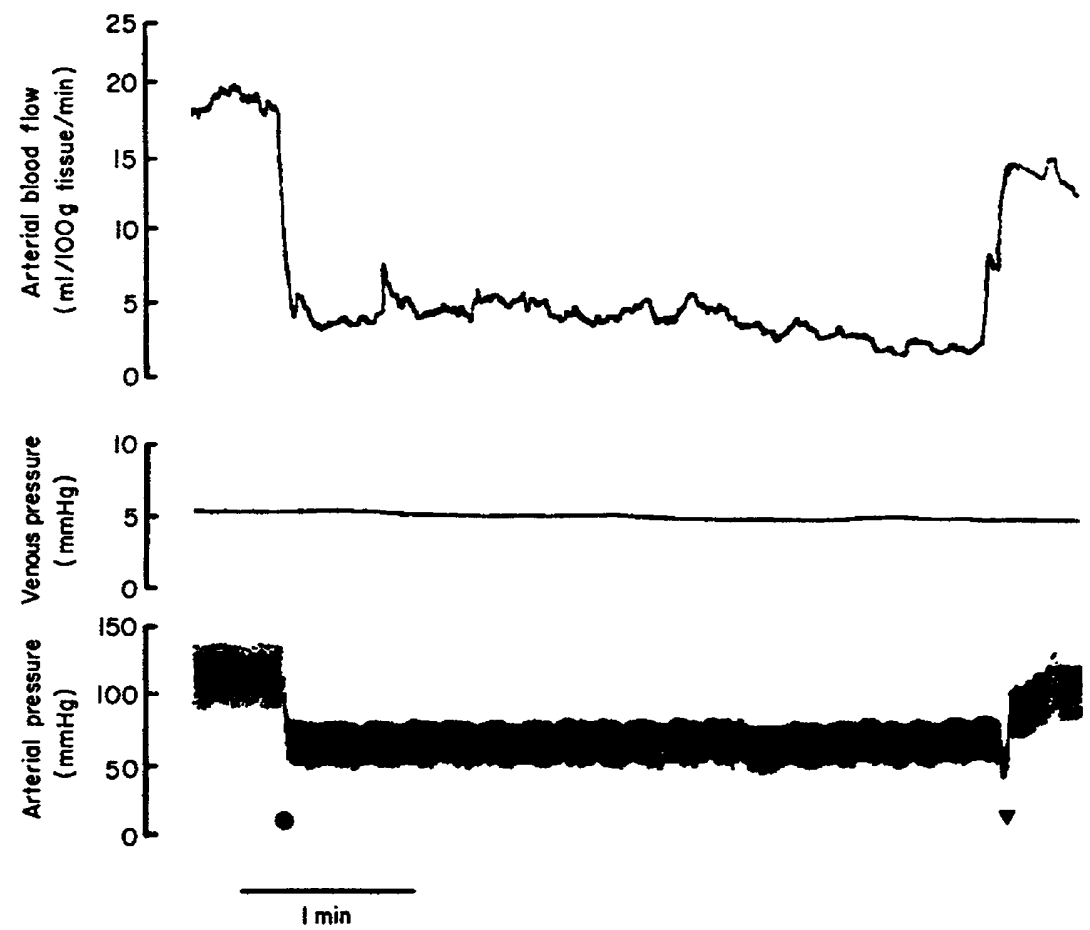

TEXT-Fig. 3. The effect of a 4-min partial occlusion of uterine blood flow in a 28-day pregnant rabbit. The upper trace shows a continuous record of left uterine arterial blood flow using the Doppler flow probe. The lower traces show the left uterine venous and left femoral arterial blood pressures. The period of occlusion is shown by the two symbols beneath the arterial pressure trace. Since the occluding cuff is applied to the lower end of the aorta, the femoral and uterine arterial pressures are similar.

\section{DISCUSSION}

The measurements obtained using the drop recorder or the Doppler flowmeter techniques of blood flow in the uterine artery of pregnant rabbits towards the end of gestation were found to be in good agreement, being $23.6 \pm 3.2$ and $27 \cdot 1 \pm 1.8 \mathrm{ml} / 100 \mathrm{~g}$ tissue $/ \mathrm{min}(t=0.44, P>0 \cdot 1)$, with mean total flows for one horn of $12.5 \pm 1.9$ and $16.8 \pm 1.4 \mathrm{ml} / \mathrm{min}$. The method of expressing blood flow in terms of weight of tissue perfused, i.e. uterus and placentae but excluding fetuses and amniotic fluid, was more satisfactory as it was shown to be less 
variable than flow expressed merely in terms of $\mathrm{ml} / \mathrm{min}$. McLaurin \& Cotter (1967), using the diffusion equilibration technique, obtained a value of 27 $\mathrm{ml} / \mathrm{min}$ for blood flow to both uterine horns of the rabbit on the 28th day of gestation. Duncan \& Lewis (1969) used an electromagnetic flowmeter in an extra-corporeal loop connected to the uterine arteries, and obtained a value of $45 \mathrm{ml} / \mathrm{min}$ for blood flow to both uterine horns. In a later study using radiolabelled microspheres, however, Duncan (1969) reported a value of $31 \mathrm{ml} / \mathrm{min}$ for blood flow to both uterine horns, and she suggested that the extra-corporeal loop had supplied some other tissues by a small inaccessible lumbar vessel. Thus, values for uterine blood flow, corrected for flow to both horns, obtained by five widely differing techniques, i.e. Doppler flowmeter $(33.6 \mathrm{ml} / \mathrm{min})$, drop recorder $(25.0 \mathrm{ml} / \mathrm{min})$, diffusion equilibration $(39.6 \mathrm{ml} / \mathrm{min})$, electromagnetic flowmeter $(45 \mathrm{ml} / \mathrm{min})$ and radio-labelled microspheres $(31 \mathrm{ml} / \mathrm{min})$, agree very well.

In the present work using the simple drop recorder technique, better results than those previously published were obtained. This was undoubtedly due to the use of a wide bore streamlined system with a very low resistance. The advantages of the Doppler probe system for measuring uterine blood flow were that a continuous record of blood flow could be made and no cannulation was required.

The fixation with formol saline of a short $(6 \mathrm{~mm})$ length of artery directly under the probe would not be expected to interefere with blood flow. Normally, very little pressure drop occurs along main arteries and the resistance and capacitance vessels were well separated from the point of application of the probe.

In the present study, various degrees of arterial occlusion were used to reduce uterine blood flow and, once reduced, this always remained constant for the duration of the occlusion ( 1 to $1.5 \mathrm{~min}$ ), indicating the absence of any reserve of reflex control of uterine vascular resistance. Reduction of uterine blood flow for $4 \mathrm{~min}$, a period thought to be sufficient to evoke metabolically induced vasodilatation, did not result in any change of vascular resistance. On removal of the occlusion, blood flow returned to the original level with no overshoot. A prolonged overshoot of flow after the period of occlusion would have been indicative of hyperaemia, a special manifestation of autoregulation. The absence of hyperaemia and any change in vascular resistance following reduced blood flow seems to indicate the absence of an autoregulatory mechanism with regard to pressure and flow in the pregnant rabbit uterus. Jones (1966) has pointed out that the type of anaesthesia used could affect the results of pressure-flow studies. It is unlikely, however, that sodium pentobarbitone, in the dosage used in the present study, would interfere with autoregulation as this substance has been used in other studies in which autoregulation has been demonstrated (Jones \& Berne, 1964; Hinshaw, 1964).

Teleologically, it might have been expected that the gravid uterus would have some autoregulatory mechanism capable of maintaining, under a variety of adverse stimuli, the blood flow necessary to accommodate the metabolic needs of the fetus, but this appears not to be the case in the rabbit, or in the sheep (Greiss, 1966a). Several workers (Greiss, 1966b; Romney, Gabel \& 
Takeda, 1963) have shown that in sheep and dogs there is an increase in uterine vascular resistance during haemorrhagic shock, suggesting that the uterine vasculature participates in the generalized adrenergic response to blood loss and is thus not a privileged vascular bed.

The pressure-flow curves from vascular beds such as the pulmonary vascular bed, which do not show autoregulation, are usually curvilinear with the convexity towards the pressure axis (Green, Rapela \& Conrad, 1963). The results obtained in the present study indicate a linear relationship between pressure and flow with the regression line cutting the pressure axis at about $10 \mathrm{mmHg}$. Greiss (1966a) and Ladner et al. (1970) also demonstrated a linear relationship between pressure and flow in the uterine vascular bed of the pregnant ewe. A possible explanation for this finding is reflex vasodilatation in the uterine vasculature following reduction in pressure. No change in vascular resistance was observed, however, when perfusion pressure was reduced. In the ewe, direct vasodilator innervation of the uterine vasculature is absent (Greiss \& Pick, 1964; Greiss \& Gobble, 1967; Greiss, Gobble, Anderson \& McGuirt, $1967 \mathrm{a}, \mathrm{b})$, though this does not exclude the possibility that vasodilatation may result from a decrease in vasoconstriction. In fact, Carter \& Olin (1972) have shown that an increase in uterine and placental blood flow can occur in the rabbit following administration of an $\alpha$-adrenoceptor blocker, though not of a $\beta$-receptor agonist such as isoprenaline.

Greiss (1966a) explained the linear relationship between pressure and flow in his experiments in the ewe as being the result of incomplete occlusion of anastomotic connections of the uterine vascular bed with collateral beds. In the present study, however, great care was taken to ensure that all connections were occluded.

A satisfactory explanation for the present findings can be found by reference to the work of Green, Lewis, Nickerson \& Heller (1944). These authors demonstrated that the relationship between blood pressure and blood flow is a power function of $F=C . P^{n}$, where $F=$ flow in $\mathrm{ml} / \mathrm{min} ; \mathrm{C}=\mathrm{a}$ constant; $\mathrm{P}=$ arterio-venous pressure difference in $\mathrm{mmHg}$, and $\mathrm{n}=$ an exponent having a value between 1 and 3 .

The lowest values of ' $n$ ' were found in dilated vascular beds and the highest were in beds with a high vasomotor tone. Levy \& Share (1953) have shown that, in the dog hind limb, maximal dilatation of the vascular bed produced by a 10-min period of ischaemia and subsequent perfusion with hypoxic blood, gives a value for ' $n$ ' of 1 . With $n=1$, the flow-pressure relationship becomes $F=$ C. P, a linear relationship. In the present work, therefore, the linear relationship between pressure and flow in the uterus indicates that, under the conditions of study, the uterine vascular bed of the pregnant rabbit is fully dilated. This being the case, no autoregulatory behaviour could be expected to be seen at pressures equal to or below maternal blood pressure as further dilatation of the uterine vasculature would be impossible. It is possible, however, that when some degree of vascular smooth muscle tone is present, as when vasoconstrictor drugs are infused, autoregulatory control of blood flow might occur. We have been able to demonstrate that during the infusion of various vasoconstrictors, $5 \mathrm{HT}$, angiotensin and noradrenaline, to the uterine bed, an escape pheno- 
menon can be observed (F. M. Sullivan and J. F. Tucker, unpublished observations).

\section{AGKNOWLEDGMENTS}

We are grateful to the Foundation for Child Development, New York, and to the National Fund for Research into Crippling Disease, London, for financial support.

\section{REFERENCES}

Ahtquist, R. P. \& Woodbury, R. A. (1947) Influence of drugs, and uterine activity upon uterine blood flow. Fedn Proc. Fedn Am. Socs exp. Biol. 6, 305.

Assali, N. S., Douglass, R. A., Baird, W. W., Nicholson, D. B. \& Suyemoto, R. (1953) Measurement of uterine blood flow and uterine metabolism. Am. F. Obstet. Gynec. 66, 11-17.

Assali, N. S. \& Morris, J. A. (1964) Maternal and fetal circulations and their interrelationships. Obstet. Gynec. Surg. 19, 923-948.

Barcroft, J., Herkel, W. \& Hill, S. (1933) The role of blood flow and gaseous metabolism of the uterus during pregnancy. F. Physiol., Lond. 77, 194-206.

BRUCE, N. W. \& ABDUL-KARIM, R. W. (1973) Relationship between fetal weight, placental weight and maternal placental circulation in the rabbit at different gestational ages. F. Reprod. Fert. 32, 1524.

Garter, A. M., Lewis, P. J. \& Bengtsson, L. P. (1966) Effects of vasopressin on uterine blood flow in the rabbit. Acta pharmac. tox. 24, 435-442.

CARTER, A. M. \& Olin, T. (1972) Effect of adrenergic stimulation and blockade on the uteroplacental circulation and uterine activity in the rabbit. F. Reprod. Fert. 29, 251-261.

Duncan, S. L. B. (1969) The partition of uterine blood flow in the pregnant rabbit. F. Physiol., Lond. $204,421-435$.

Duncan, S. L. B. \& Lewis, B. V. (1969) Maternal placental and myometrial blood flow in the pregnant rabbit. F. Physiol., Lond. 202, 471-483.

Gosling, R. G., King, D. H., Newman, D. L. \& Woodcock, J. P. (1969) Transcutaneous measurement of arterial blood-velocity by ultrasound. In Ultrasonics for Industry, pp. 16-23.

Gothlin, J. \& Carter, A. M. (1969) Pelvic angiography in the female rabbit. Investve Radiol. 4, 45-49.

GreEN, H. D., Lewis, R. N., NICKerson, N. D. \& Heller, H. L. (1944) Blood flow, peripheral resistance and vascular tonus with observations on the relationship between blood flow and cutaneous temperature. Am. F. Physiol. 141, 518-534.

Green, H. D., RApela, G. F. \& ConRad, M. G. (1963) Resistance (conductance) and capacitance phenomena in terminal vascular beds. Handbook of Physiology: Section 2: Circulation, Vol. II, pp. 935-960. Eds. W. F. Hamilton, and P. Dow. Williams \& Wilkins, Baltimore.

Greiss, F. G. (1966a) Pressure-flow relationship in the gravid uterine vascular bed. Am. F. Obstet. Gynec. 96, 41-47.

GREIss, F. G. (1966b) Uterine vascular response to hemorrhage during pregnancy. Obstet. Gynec., N.Y. 27, 549-554.

GreIss, F. G. \& GobBLE, F. L. (1967) Effect of sympathetic nerve stimulation on the uterine vascular bed. Am. F. Obstet. Gynec. 97, 962-967.

Greiss, F. G., Gobble, F. L., Anderson, S. G. \& McGurrt, W. F. (1967a) Effect of parasympathetic nerve stimulation on the uterine vascular bed. Am. F. Obstet. Gynec. 99, 1067-1073.

Greiss, F. C., Gobble, F. L., ANDerson, S. G. \& McGuirT, W. F. (1967b) Effect of acetyl choline on the uterine vascular bed. Am. F. Obstet. Gynec. 99, 1073-1077.

Greiss, F. C. \& PIGK, J. R. (1964) The uterine vascular bed: adrenergic receptors. Obstet. Gynec., N.Y. 23, 209-213.

Hinshaw, L. B. (1964) Mechanisms of renal autoregulation. Circulation Res. 15, Suppl. 1, 120-129.

Huckabee, W. E. (1962) Uterine blood flow. Am. J. Obstet. Gynec. 84, 1623-1633.

Jones, H. C. (1966) Comment. Am. F. Obstet. Gynec. 96, 46-47.

JoNEs, R. D. \& BERNE, R. M. (1964) Local regulation of blood flow in skeletal muscle. Circulation Res. 15, Suppl. 1, 30-38.

Ladner, C., Brinkman, C. R., III, Weston, P. \& Assali, N. S. (1970) Dynamics of uterine circulation in pregnant and non-pregnant sheep. Am. F. Physiol. 218, 257-263.

LEVY, M. N. \& SHARE, L. (1953) The influence of erythrocyte concentration upon the pressure flow relationships in the dog's hind limb. Circulation Res. 1, 247-255.

Malaurin, L. P. \& Cotter, J. R. (1967) Placental transfer of iron. Am. J. Obstet. Gynec. 98, 931-937. 
Meschia, G., Cotter, R., Makowski, E. L. \& Barron, D. H. (1966) Simultaneous measurement of uterine and umbilical blood flows and oxygen uptakes. Q. Fl exp. Physiol. 52, 1-18.

REYNOLDS, S. R. M. (1947) Relationship between uterine blood flow and duration of pregnancy in the rabbit. Am. F. Physiol. 148, 77-85.

Robson, J. M. \& Schmb, H. O. (1938) Effect of drugs on the blood flow and activity of the uterus. F. Physiol., Lond. 92, 9-19.

Romney, S. L., GABeL, P. V. \& TAKEDA, Y. (1963) Experimental hemorrhage in late pregnancy. Am. F. Obstet. Gynec. 87, 636-645. 